[The Editor has had the pleasure, on three occasions, to see and examine Mr. Pengelly's interesting rock-specimens, exhibiting Molluscan borings, and he has no hesitation in referring them to Pholas, as they agree perfectly with specimens in the late Dr. Woodward's cabinet, which still contain the valves of Pholas within the cavity.]

We are requested by Mr. Mackintosh to correct his letter in our last No. as follows:--Page 137, line 16, for "planes," read plainsline 30 for "These," read Those; page 138, line 1 (in notes) for " these," read those-line 4 (in notes) delete "which"-line 16 (in notes) for "dualogical" reasoning, read analogical reasoning.]

\title{
AGE AND POSITION OF THE DRIFT DEPOSITS OF THE EASTERN
} COUNTIES.

\section{To the Editor of the Geologican Magazine.}

Srr,-You will, perhaps, allow me to explain, and correct, an opinion which Mr. Maw, in his paper in the last number of the Magazine, has attributed to me.

He quotes (page 99) my expression that the Chillesford beds are evidently part of the Middle Drift; but he seems to have overlooked a qualification of that opinion which $I$ subsequently made. When the remarks which Mr. Maw quotes were written, I had traced the Till and Contorted Drifts of the Cromer coast ( $a$ and $b$ of Mr. Maw's fig. 1), from the Weybourne extremity of the coast section into a marl, which passed inland under the Middle Drift (or bed D of the figure), until I found it thin out against the Chalk, before the Crag district was reached. Hence, as the Middle Drift was a capping bed common to these beds, the Crag, and the Chillesford clay, alike, I was induced from the appearance of the latter at Chillesford, Sudbourn, and Orford, to regard them as belonging to the lower part of the Middle Drift formation. Subsequently to this, however, I succeeded in tracing the beds of the Cromer coast from the other, or Hasboro', extremity of the coast, section (which I had previously only traced under the Middle Drift sands as far as North Walsham) completely over the Chillesford clays, and the Fluvio-marine Crag of Norwich.

In doing so, I availed myself of the labours of Mr. Harmer, of Norwich, who systematically worked out and mapped a considerable area on the east and north of that city. This gentleman found that the Green Clay worked for bricks, into which the Cromer beds pass from Hasboro', by North Walsham, to the Bure Valley, had an extensive spread beneath the Middle Drift on the north of Norwich; and with it passed under the Upper Drift, at Trowse and Arminghall, on the south of the city. This green clay in the Bure Valley is underlaid by a sand containing pebble beds, which, at Coltishall and Wroxham, yields a small proportior of the shells of the Fluviomarine and Red Crags, and of the Chillesford bed. Mr. Harmer and myself found this green clay to pass over the Crag, a pit of it occurring on the bill above the Thorpe pit, and close to it. 
On examining the Crag pit of Thorpe more closely, I found the pebbly cands of the Bure valley to cap the pit section, resting upon the attenuated Chillesford clay. Mr. Harmer had detected a bed of blue clay, about twelve feet thick, interstratified with sand bands, over a considerable area on the south-east of Norwich, which was quite distinct from the before-mentioned green clay. This I at once recognized as the Chillesford clay, and found it to be present in the Crag pits of Brundall, Bramerton, and Thorpe, attenuating in the latter to half its usual thickness; the Chillesford shell-bed occurring in all three, in its usual place in the sands beneath the clay. The exposure of (so-called) Crag at Toftmonks, in the Waveney valley, made known by Mr. Rose, I recognized also as the Chillesford clay and shell-bed; and was thus enabled, by an almost continuous line of sections, to trace these clays from Norwich, where they pass under the Bure Valley beds and green clay, to Easton cliff, from which they are admitted to extend to Chillesford.

On analysing with my father the fauna (as far as known), we found the sequence of the four formations to be in the following ascending order, viz:-1, Fluvio marine Crag; 2. Chillesford bed; 3. Bure valley beds; 4. Weybourne sand (or so-called Norwich Crag of the coast); which precisely agreed with their position, deduced by me from the sections as above explained. I was then satisfied that I had been misled by the apparent transition from the Chillesford clay to the Middle Drift, which the sections around Qrford, Sudbourn, and Chillesford seemed to indicate; and I took the opportunity of a note to the structural diagram of the beds from the Red Crag upwards, which I gave in my father's paper on the Red Crag (Quarterly Journal of the Geological Society, Vol. xxii., page 552), to correct this error; and I had hoped in a manner sufficiently intelligible.

The green clay, before mentioned, changes southwards from Norwich, first into a red loam-in which form it comes up beneath the Middle and Upper Drift, at the base of the Coast Section, between Yarmouth and Lowestoft, and at Pakefield Cliff; and then into red sand, in which form it is present over the pobbly Bure valley sands on the top of the Covehithe and Easton Cliffs, and comes up beneath the Middle Drift in the lower part of Dunwich Cliffo. About this part also the Bure Valley beds lose their pebbles; and thue all the beds between the Chillesford clay and the Upper Drift, becoming, as they approach Orford, Sudbourn, and Chillesford, gimple sand, the illusory appearance of this part of the area is produced.

I take the opportunity of demurring to the altitude of any glacial, or post-glacial, bed, being regarded as a test of its age, except where two beds oceur in close contiguity to form a terrace; and then no further than as a test inter se. I hardly think that Mr. Maw is aware that the clay, of which he speaks as occupying heights from 150ft. to $230 \mathrm{ft}$, above the sea, descends from High Suffolk and Norfolk (underlaid by the Middle Drift) gradually to the sea level at Scratby Cliff; and to within 30ft. of it at Corton and Pakefield 
Oliff ; while, in the opposite direction, after overlapping the Middle Drift, it reaches to the crests of the Downs over Royston and Baldock-heights, I imagine, exceeding those he gives for it in his paper.

Searles V. Wood, Jun.

Brentwaod, Essex.

\section{MISCEITANEOUS.}

Lectures on Mining.-In a previous number of the Magazine, attention was directed to the course of lectures on practical mining being given by Professor Smyth, and reported in the Mining Journal; the following are the heads of the subjects treated of, in continuation of those previously alluded to, viz. :- On the driving of levels, and the direction which ought to be taken in seeking deposits which have been lost; on securing the ground by timber. ing, and the relative value of the different kinds of wood that are used in England and other countries, the nature of the ground to be timbered, and the necessary precautions to be adopted; on the employment of stone and other materials in walling; on the sinking, position, form, and size of shafts, in relation to the nature of the strata to be passed through, and the modes of securing and protecting their sides; on tubbing, and the methods used for sinking through difficult ground, in which the ingenious suggestion of $\mathbf{M}$. Triger is fully described. Following the nature of exploratory and other works, called dead work, Professor Smyth treated of the difference in working metalliferous and stratified deposits, and on some deposits which were worked by methods common to both. These lectures successively appear in the Mining Journal, and are carefully and somewhat fully reported, and will be found useful records to the studenta who attend the lectures, and instructive to those who have not had the opportunity of hearing them.-J. M.

The $R_{\text {HYNChocetr }}$ of THE Crag.-The group of Cetaceans called by Eschricht Rhynchoceti, from their remarkable beak-like muzzle, are represented in the present fauna by about six species, belonging to four or five genera, according to Professor Huxley (Quart. Journ. Geol. Soc. 1864, p. 395). The species described by M. Fischer, as noted in our February number, probably belongs to one of these genera. The fossil Rhynchoceti at present known are the Ziphius cavirostris of Cuvier, of doubtful age; Choneziphius planirostris, from the Lower Antwerp Crag; and nine species belonging to the genus Belemnoziphius, of which seven are known only from our English Red Crag; Choneziphius has never yet been recorded as occurring in our Suffolk strata, and is known alnost solely from a fine specimen discovered at Antwerp, $\rightarrow$ a cast of which is in the British Museum. Mr. Ray Lankester informs us that two years since he identified a large specimen of a Rhynchocetan skull from the Red Crag, with the cast of Choneziphius in the British Museum, and that the identification was confirmed by Professor Huxley. The specimen was then in the possession of Mr. John Calvert, and was almost as perfect and satis- 